\title{
Occurrence of Infectious Fish Diseases in Fish Farms in Northern Finland
}

\author{
By Keränen, Koski, Kulonen, Ek-Kommonen \\ and Neuvonen
}

National Veterinary Institute, Regional Laboratory Oulu, and National Veterinary Institute, Department of Virology, Helsinki, Finland.

\begin{abstract}
Keränen A.-L., P. Koski, K. Kulonen, C. Ek-Kommonen and E. Neuvonen: Occurrence of infectious fish diseases in fish farms in Northern Finland. Acta vet scand. 1992, 33, 161-167. - A total of 47 fish located in 10 lake and river systems in northern Finland were examined for furunculosis, enteric redmouth diseases (ERM), viral fish diaseses and the parasite Gyrodactylus salaris. Furunculosis was found in 2 fish farms in different watercourses, ERM in 8 fish farms in 3 watercourses and viral diseases were not found at all. G. salaris was looked for only in salmon and rainbow trout and was found in both species in 3 farms belonging to 2 watercourses.
\end{abstract}

yersiniosis; furunculosis; Gyrodactylus salaris.

\section{Introduction}

Fish is reared in northern Finland for food and for stocking of natural waters. Mainly salmonids are produced intensively, while whitefish (Coregonus species) are raised more extensively in natural food ponds. About 1/10 of the Finnish fish farmed for food or stocking are produced in northern Finland, and about $80 \%$ of the area of natural food ponds in the country is situated in this region.

Atypical strains of Aeromonas salmonicida have been incriminated as a cause of fish disease in Finland since the mid 1960's (Ojala 1966), A. salmonicida ssp. Achromogenes from 1982 (Anon. 1982) and A. salmonicida ssp. salmonicida from 1986 (Rintamäki \& Koski 1987). Yersinia ruckeri infection was found in salmonids in 1982 (Rintamäki et al. 1986). Of the viral fish diseases, infectious pancreatic necrosis (IPN) was found in 1984 (Anon. 1984) and a serologically distinct new rhabdovirus in 1987 (Koski 1988). The monogenean parasite Gyrodactylus salaris Malmberg has been found at fish farms since 1986 (Rimaila-Pärnänen \& Wiklund 1987, Rimaila-Pärnänen 1989, Rintamäki 1989).

The present report concerns with the occurrence of furunculosis caused by $A$. salmonicida ssp. salmonicida, $Y$. ruckeri infection (Enteric Redmouth Disease, ERM), viral diseases and G. salaris infection identified at fish farms in northern Finland in 1988.

\section{Materials and methods}

Forty seven fish farms, of which 28 produced fish fry, located in 10 river and lake systems in the provinces of Lapland and Oulu were selected for the survey (Fig. 1). At least the lowest situated fish farm in each river system was examined.

Sixty fish of each farmed species were examined from each farm (McDaniel 1979). A total of 3420 fish from the 47 farms were examined bacteriologically and 2250 fish from the 30 farms in 9 river systems were examined 


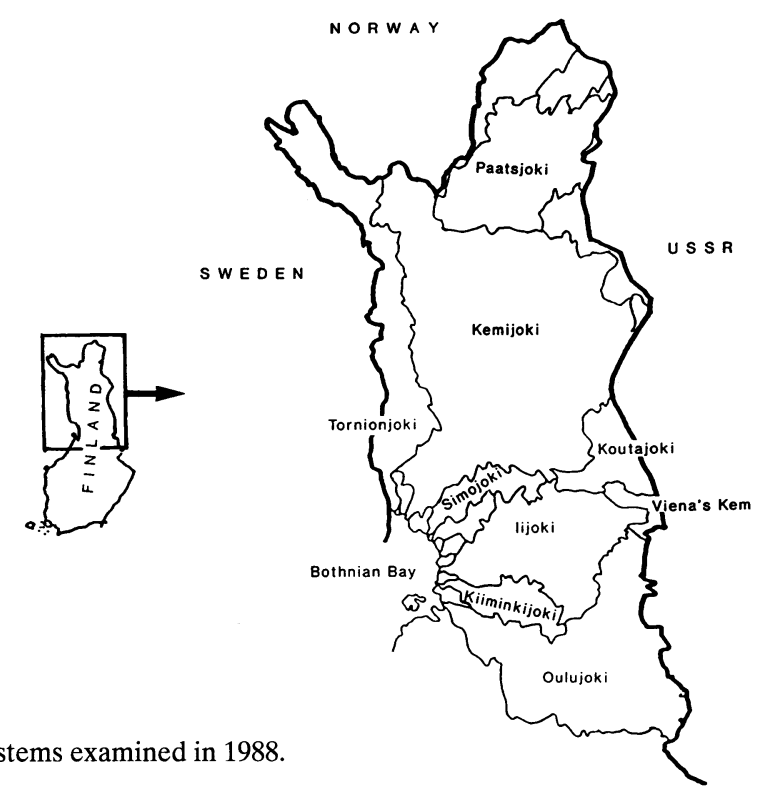

Figure 1. The 10 waterway systems examined in 1988.

virologically. The number of fish taken are shown in Tables 1 and 2. G. salaris was examined during the cool water period, October-May $\left(<10^{\circ} \mathrm{C}\right)$, at 16 fish farms in 5 river systems as seen in Table 3. Sampling took place from February to October 1988. The fish were brought either alive or killed and on ice to the National Veterinary Institute Regional Laboratory in Oulu.

During the warm water season, June-September $\left(10-21^{\circ} \mathrm{C}\right)$, the fish were examined bacteriologically by the direct streaking

Table 1. Numbers of fish of 5 species from 10 waterway systems in northern Finland examined bacteriologically.

\begin{tabular}{|c|c|c|c|c|c|c|}
\hline \multirow[b]{2}{*}{ Water system } & \multicolumn{5}{|c|}{ No. of fish examined } & \multirow{2}{*}{$\begin{array}{c}\text { Total } \\
\text { fish } \\
\text { examined }\end{array}$} \\
\hline & Salmon & $\begin{array}{c}\text { Rainbow } \\
\text { trout }\end{array}$ & $\begin{array}{l}\text { Sea } \\
\text { trout }\end{array}$ & $\begin{array}{c}\text { Brown } \\
\text { trout }\end{array}$ & $\begin{array}{c}\text { Brook } \\
\text { trout }\end{array}$ & \\
\hline Oulujoki & 60 & 540 & - & 300 & - & 900 \\
\hline Kiiminkijoki & - & 60 & - & - & - & 60 \\
\hline Iijoki & 120 & 450 & - & 220 & 60 & 850 \\
\hline Simojoki & 60 & - & - & - & - & 60 \\
\hline Kemijoki & 270 & 320 & 30 & 120 & - & 740 \\
\hline Tornionjoki & 120 & 60 & - & 60 & - & 240 \\
\hline Viena's Kem & - & - & - & 60 & - & 60 \\
\hline Paatsjoki & - & - & - & 120 & - & 120 \\
\hline Koutajoki & - & 90 & - & 60 & - & 150 \\
\hline \multirow[t]{2}{*}{ Bothian Bay } & - & 180 & 60 & - & - & 240 \\
\hline & 630 & 1700 & 90 & 940 & 60 & 3420 \\
\hline
\end{tabular}


Table 2. Numbers of fish of 5 species from 9 waterway systems in northern Finland examined virologically.

\begin{tabular}{|c|c|c|c|c|c|c|}
\hline \multirow[b]{2}{*}{ Water system } & \multicolumn{5}{|c|}{ No. of fish examined } & \multirow{2}{*}{$\begin{array}{c}\text { Total } \\
\text { fish } \\
\text { examined }\end{array}$} \\
\hline & Salmon & $\begin{array}{c}\text { Rainbow } \\
\text { trout }\end{array}$ & $\begin{array}{l}\text { Sea } \\
\text { trout }\end{array}$ & $\begin{array}{c}\text { Brown } \\
\text { trout }\end{array}$ & $\begin{array}{c}\text { Brook } \\
\text { trout }\end{array}$ & \\
\hline Oulujoki & 120 & 180 & - & 300 & - & 600 \\
\hline Iijoki & 150 & 180 & 60 & 120 & - & 510 \\
\hline Simojoki & 60 & - & - & - & - & 60 \\
\hline Kemijoki & 180 & 180 & - & 120 & 60 & 540 \\
\hline Tornionjoki & 120 & - & - & 60 & - & 180 \\
\hline Viena's Kem & - & - & - & 60 & - & 60 \\
\hline Paatsjoki & - & - & - & 120 & - & 120 \\
\hline Koutajoki & - & - & - & 60 & - & 60 \\
\hline \multirow[t]{2}{*}{ Bothian Bay } & 60 & - & 60 & - & - & 120 \\
\hline & 690 & 540 & 120 & 840 & 60 & 2250 \\
\hline
\end{tabular}

technique, in which samples were taken from the kidney and posterior intestine. Blood agar (tryptone soy agar with $5 \%$ defibrinated bovine blood) and modified Shotts-Waltman agar (SW) containing $0.3 \mathrm{~g}$ bromthymol blue (Waltman \& Shotts 1984) were used. The incubation period was 7 days at $+22^{\circ} \mathrm{C}$, and the plates were examined daily. Bacterial colonies were identified using the tests shown in Table 4 (Wichardt 1983, Bercovier \& Mollaret 1984, Popoff 1984, Austin \& Austin 1987).

During the cool water period specimens for virus and $G$. salaris examination were collec- ted and carriers of $A$. salmonicida spp. salmonicida and Y. ruckeri were searched for by the stressing method (Bulloch \& Stuckey 1975). The fish were brought alive to the laboratory in Oulu where they were placed in aerated plastic tanks with approximately $10 \mathrm{~kg}$ fish/1000 1 water. They were then anaesthetized with MS-222 (Sandoz, Switzerland) or Benzocainum Ph. Eur. (Tamro, Finland) and injected intraperitoneally with a corticosteroid (Depo-Medrol (Upjohn, Belgium), dosage $10 \mathrm{mg} / \mathrm{kg}$ fish). The water temperature in tanks was raised to $+18^{\circ} \mathrm{C}$, and the fish were kept in the tanks for at least 2

Table 3. Numbers of fish examined for Gyrodactylus salaris, and its occurrence at fish farms in 5 waterway systems in northern Finland.

\begin{tabular}{|c|c|c|c|c|c|}
\hline \multirow[b]{2}{*}{ Water system } & \multirow{2}{*}{$\begin{array}{l}\text { No. of farms } \\
\text { examined }\end{array}$} & \multirow{2}{*}{$\begin{array}{l}\text { No. of farms } \\
\text { infected }\end{array}$} & \multicolumn{2}{|c|}{ No. of fish examined } & \multirow{2}{*}{ Tot. fish examined } \\
\hline & & & Salmon & Rainbow trout & \\
\hline Oulujoki & 4 & 0 & 60 & 180 & 240 \\
\hline Iijoki & 3 & 2 & 60 & 120 & 180 \\
\hline Kemijoki & 5 & 1 & 180 & 180 & 360 \\
\hline Tornionjoki & 2 & 0 & 120 & - & 120 \\
\hline \multirow[t]{2}{*}{ Bothian Bay } & 2 & 0 & 60 & 60 & 120 \\
\hline & 16 & 3 & 480 & 540 & 1020 \\
\hline
\end{tabular}


Table4. Results of the biochemical tests used to identify different subspecies of Aeromonas salmonicida and Yersinia ruckeri.

\begin{tabular}{|c|c|c|c|c|}
\hline & $\begin{array}{l}\text { A salmonicida } \\
\text { ssp. } \\
\text { salmonicida }\end{array}$ & $\begin{array}{l}\text { A. salmonicida } \\
\text { ssp. } \\
\text { achromogenes }\end{array}$ & & Y. ruckeri \\
\hline Gram staining & - & - & Gram staining & - \\
\hline Motility & - & - & Motility $+22^{\circ}$ & + \\
\hline Morphology & short rod & short rod & $+37^{\circ}$ & - \\
\hline Cytochrome oxidase & + & + & Morphology & rod \\
\hline $\mathrm{O} / \mathrm{F}$ test & $+/+$ & $+/+$ & Cytochrome oxidase & - \\
\hline Haemolysis (bovine) & + & - & $\mathrm{O} / \mathrm{F}$ test & $+/+$ \\
\hline Prod. brown pigment* & + & - & Tween 80 & + \\
\hline Sucrose & - & + & Colony size $/ 24 \mathrm{~h}$ & $<1 \mathrm{~mm}$ \\
\hline Maltose & + & + & Voges-Proskauer $+37^{\circ}$ & - \\
\hline Gas from maltose & + & - & Methyle red $+22^{\circ}$ & $+/-$ \\
\hline Esculine & + & - & $+37^{\circ}$ & $+/-$ \\
\hline Mannitole & + & + & Esculine & - \\
\hline Indole & - & - & Gelatine & + \\
\hline Salicin & + & - & Lecithinase & + \\
\hline Arbutine & + & - & L-arabinose & - \\
\hline Xylose & - & - & Xylose & - \\
\hline Nitrate reduction & + & + & Citrate (Simmons) & + \\
\hline Trehalose & + & - & API $20 \mathrm{E} / 24 \mathrm{~h},+22^{\circ}$ & \\
\hline \multicolumn{5}{|l|}{ Sensitivity to } \\
\hline ampicillin $(33 \mu \mathrm{g})$ & + & - & & \\
\hline cefalothin $(66 \mu \mathrm{g})$ & + & - & & \\
\hline
\end{tabular}

* tryptic soy agar

Test are selected according to the earlier reports by Wichardt (1983), Berchovier \& Mollaret (1984), Popoff (1984), Austin \& Austin (1987).

weeks after the injection. Fish dying during the test and all the fish alive at the end of the experiment were examined bacteriologically by the direct streaking technique.

The enrichment method (Hirvelä-Koski et al. 1988) was used 3 times in addition to the direct streaking technique, pieces of kidney or spleen were taken as samples.

Small fish were collected for virological examination (see McDaniel 1979), and samples were taken from fry in the spring and from fingerlings in the autumn. Samples were also taken from older fish at 18 farms in 8 river systems. The samples from 10 fish were poo- led on each occasion. The pooled organs were homogenized in the cell culture medium and centrifuged (700 g, $30 \mathrm{~min},+4^{\circ} \mathrm{C}$ ). The supernatant was diluted $1: 10$ and filtered through a $0.45 \mu \mathrm{m}$ filter (Schleicher \& Schuell, Germany). Transport tubes with the filtrated supernatant were sent to the virus laboratory in Helsinki, where virus isolation were performed in RTG-2 and BF-2 cells (Anon. 1986).

The pectoral fins of fish brought alive to the laboratory were examined during the cool water period for the presence of $G$. salaris. Identifications were performed by Dr. Göran 
Malmberg in Sweden. The fish kept in the stressing tanks were not examined parasitologically.

\section{Results}

The results of the bacteriological examinations are shown in Table 5. Carriers of $\mathrm{A}$. salmonicida spp. salmonicida were detected among rainbow trout, Oncorhynchus mykiss (Walbaum), in the coast of the Bothnian Bay, and salmon, Salmo salar L., in the Iijoki water system. The case in the Bothnian Bay was diagnosed by the enrichment method only and that in the Iijoki water system by the stressing method. A. salmonicida ssp. achromogenes was isolated from diseased sea trout, $S$. trutta m. trutta (L.) at 1 farm in the Kemijoki water system by the direct streaking technique.

Y. ruckeri was isolated from symptomless fish in 3 river systems, once from rainbow trout and 3 times from brown trout, $S$. trutta $\mathrm{m}$. lacustris (L.), in the Oulujoki water system, twice from brown trough in the Iijoki system, and twice from salmon in the Kemijoki system. Seven of the isolations were found by the stressing method and that from the rainbow trout by the direct streaking technique. The serotypes of these isolates were not determined.

All the samples examined virologically were negative.

G. salaris was looked for only in salmon and rainbow trout. Farms were regarded as positive even when $1 G$. salaris was found. Prevalence and intensity of infection was not observed in this examination. G. salaris was detected in both fish species at 3 fish farms in the Iijoki and Kemijoki systems (Table 3). In addition, Gyrodactylus sp. (no. 9 in Malmberg \& Malmberg 1987) was found in rainbow trout at 1 farm in the Oulujoki river system.

\section{Discussion}

As a general prevalence survey, the sampling was to some degree biased, since a deliberate search was made for carrier fish. Also, the brown trout of the Oulujoki river system were examined more intensively for viruses

Table 5. Numbers of farms in 10 waterway systems in northern Finland, farms examined bacteriologically and virologically and numbers of farms found positive for furunculosis (Aeromonas salmonicida ssp. salmonicida) and enteric redmouth disease, ERM (Yersinia ruckeri). All the farms examined virologically were negative.

\begin{tabular}{lcccccc}
\hline & Total no. of farms & \multicolumn{2}{c}{$\begin{array}{c}\text { No. of farms } \\
\text { examined for }\end{array}$} & & \multicolumn{2}{c}{ No. of farms positive for } \\
\cline { 3 - 5 } Water system & & 11 & 8 & & Furunculosis & ERM \\
\hline Oulujoki & 36 & 1 & 0 & 0 & 4 \\
Kiiminkijoki & 1 & 10 & 5 & 0 & 0 \\
Iijoki & 26 & 1 & 1 & 1 & 2 \\
Simojoki & 1 & 11 & 9 & 0 & 0 \\
Kemijoki & 26 & 3 & 2 & 0 & 0 \\
Tornionjoki & 3 & 1 & 1 & 0 & 0 \\
Viena's Kem & 4 & 2 & 2 & 0 & 0 \\
Paatsjoki & 2 & 3 & 1 & 0 & 0 \\
Koutajoki & 5 & 4 & 1 & 1 & 0 \\
Bothnian Bay & 13 & 47 & 30 & 2 & 8 \\
\hline
\end{tabular}


because a serologically new rhabdovirus had been isolated there from brown trout fingerlings in 1987.

Correspondingly, as furunculosis has been diagnosed earlier in the Iijoki watercourse, the fish farms there were systematically examined for furunculosis by the stressing method.

The stressing method is more sensitive than the direct streaking technique and is considered good for searching for carriers of furunculosis and ERM among small fish $(<15 \mathrm{~cm})$. It was impossible to use the method with large fish, however, because of the small size of our stressing tanks. The enrichment technique was therefore used in these cases.

All the $Y$. ruckeri carriers were symptomless in this examination. The bacterium was found to be quite common in fish farms in northern Finland.

No viral fish diseases were found, nor did any of the fish show any clinical signs suggestive of such a disease.

The monogenean parasite $G$. salaris was found at 3 farms on rivers flowing into the Bothnian Bay. This parasite has been found only at fish farms in Finland, and apart from 1 case in salmon (Rintamäki 1989), it has not caused any problems. It has killed wild Atlantic salmon parr in several rivers in Norway (Johnsen \& Jensen 1986), but the Baltic salmon is thought to be more resistant (Bakke et al. 1990).

The situation in Finland as a whole in 1988 regarding the fish diseases under consideration here, including the present findings, was that furunculosis occurred altogether at 17 fish farms, 10 of which were in the provinces of Oulu and Lapland, ERM occurred at 22 fish farms, 13 in Oulu and Lapland, IPN was found at 4 fish farms in southern Finland, and $G$. salaris was found at 18 fish farms in 1986-88 (Rimaila-Pärnänen 1989). Furuncu- losis, ERM and IPN have been regularly identified in Norway and Sweden (Sparboe et al. 1986, Røtteren 1987, Wichardt 1988, Christie et al. 1990), but details of their occurrence in the Soviet Union are not known.

The background of the fish reared in northern Finland is variable, but the fish at all the farms examined here were of Finnish origin. Some of the farms grow their own fish, and others buy them. Most of the farms which produced fry and sold them to others were included in the present survey. The Animal Health Law places restrictions on the activities of farms where furunculosis, bacterial kidney disease (BKD), IPN or G. salaris have beed diagnosed, but the other subspecies of $A$. salmonicida and ERM are not legally controlled in Finland.

\section{Acknowledgements}

Our warm thanks are due to Dr. Göran Malmberg for identifying the Gyrodactylus material. This work was supported financially by the provincial administrations of Oulu and Lapland.

\section{References}

Anonymous: National Veterinary Institute annual report 1982. Helsinki, Finland, 1982.

Anonymous: National Veterinary Institute annual report 1984. Helsinki, Finland, 1984.

Anonymous: Zoo sanitary code, May 1986 update document. Off. Int. Epiz. Paris 1986.

Austin B, Austin DA: Bacterial fish pathogens: Disease in farmed and wild fish. Ellis Horwood Ltd. 1987.

Bakke TA, Jansen PA, Hansen LP: Differences in the host resistance of Atlantic salmon, Salmo salar L., stocks to the monogenean Gyrodactylus salaris Malmberg, 1957. J. Fish Biol. 1990, 37, 577-587.

Bercovier H, Mollaret HH: Genus XIV. Yersinia Van Loghem, 1944, 15. In: Krieg NR (ed): Bergey's manual of systematic bacteriology, Vol. 1. William \& Wilkins, Baltimore 1984, p. 498-506.

Bullock GL. Stuckey HM: Aeromonas salmonicida: Detection of asymptomatically infected trout. Prog. Fish Cult. 1975, 4, 237-239.

Christie KE, Ness S, Djupvik HO: Infectious pan- 
creatic necrosis virus in Norway: partial serotyping by monoclonal antibodies. J. Fish Dis. 1990, 13, 323-327.

Hirvelä-Koski V, Koski P, Kuoppamäki T: Enrichment in tryptic soy broth for the detection of Aeromonas salmonicida from the kidney of carrier fish. Bull. Eur. Ass. Fish Pathol. 1988, 4, 8586.

Johnsen BO, Jensen AJ: Infestations of Atlantic salmon Salmo salar, by Gyrodactylus salaris in Norwegian rivers. J. Fish Biol. 1986, 29, 233241.

Malmberg G, Malmberg M: Gyrodactylus in salmon and rainbow trout farms. In: Stenmark A, Malmberg G (eds): Parasites and diseases in natural waters and aquaculture in Nordic countries. Naturhistoriska Riksmuseet, Stockholm 1987, p. 199-204.

McDaniel $D(e d)$ : Procedures for the detection and identification of certain fish pathogens. Fish health blue book. Amer. Fish. Soc. Fish Health Section, Bethesda, Maryland 1979.

Ojala $O$ : Isolation of an aerogenic bacterium resembling Aeromonas salmonicida in spawning lake trouts. Bull. Off. Int. Epiz. 1966, 65, 793804.

Popoff M: Genus III. Aeromonas Kluyver and van Niel, 1936, 398. In: Krieg NR (ed): Bergey's manual of systematic bacteriology, Vol. 1. William \& Wilkins, Baltimore 1984, p. 545-548.

Rimaila-Pärnänen E, Wiklund T: Gyrodactylus salaris - loismadon levinneisyydestä makeanveden kalanviljelylaitoksissamme. (The occurrence of Gyrodactylus salaris in fresh water fish farms). Suomen Eläinläakärilehti 1987, 93, 506-507.

Rimaila-Pärnänen E: Ajankohtaista kalatautitilanteesta vuonna 1988. (Recent notes on fish diseases in 1988). Suomen Kalankasvattaja 1989, 3, 13-14.

Rintamäki P, Valtonen ET, Frerichs GN: Occurrence of Yersinia ruckeri infection in farmed whitefish, Coregonus peled Gmelin and Coregonus muksun Pallas, and Atlantic salmon, Salmo salar L., in northern Finland. J. Fish Dis. 1986, 9, 137-140.

Rintamäki P, Koski P: Outbreak of furunculosis in northern Finland. In Stenmark A, Malmberg G (eds): Parasites and diseases in natural waters and aquaculture in Nordic countries. Naturhistoriska Riksmuseet, Stockholm 1987, p. 121128.

Rintamäki P: Gyrodactylus salaris at a fish farm in northern Finland. In: Bauer ON (ed): Parasites of freshwater fishes of North-West Europe. Petrozavodsk 1989, p. 123-130.

Koski, P: Personal communication, 1988.

Røttereng PJ: Control of furuculosis in fresh and seawater farms in Norway. In: Stenmark A, Malmberg $G$ (eds): Parasites and diseases in natural waters and aquaculture in Nordic countries. Naturhistoriska Riksmuseet, Stockholm 1987, p. 129-130.

Sparboe O, Håstein T, Poppe TT, Koren C, Stenwig H: Yersinia ruckeri infeksjon på laks for første gang påvist i Norge. (The first reported case of Yersinia ruckeri infection in Salmon in Norway). Norsk Veterinaertidsskrift 1986, 98, 189-192.

Waltman WD, Shotts EB Jr: A medium for the isolation and differentation of yersinia ruckeri. Canad. J. Fish. Aq. Sci. 1984, 41, 804-806.

Wichardt U-P: Atypisk Aeromonas salmonicida infektion hos havsöring (Salmo trutta L.). I. Utredning klinik och bakteriologi. (Atypical Aeromonas salmonicida infection in sea trout (Salmo trutta L.). I. Epizootological studies, clinical signs and bacteriology.) Laxforskningsinstitutet Meddelande no. 6, 1983.

Wichardt U-P: Fisksjukdomssituationen i Sverige. (Occurrence of fish diseases in Sweden). Laxforskningsinstitutet Information no. 1, 1988.

\footnotetext{
Sammandrag

Fisksjukdomssituationen vid fiskodlingar $i$ norra Finland.

Totalt undersöktes 47 fiskodlingar från 10 vattensystem i norra Finland för furunkulos, enteric redmouth disease (ERM), virusbetingade infektionssjukdomar och Gyrodactylus salaris -parasit. Furunkulos fanns vid 2 odlingar i olika vattensystem, ERM vid 8 odlingar i 3 vattensystem, men virussjukdomar fanns inte. G. salaris undersöktes bara från lax och regnbåge och fanns hos båda arterna vid 3 odlingar i 2 vattensystem.
}

(Received August 10, 1991; accepted November 7, 1991).

Reprints may be requested from: A.-L. Keränen, National Veterinary Institute, Regional Laboratory Oulu, P.O. Box 517, SF-90101 Oulu, Finland. 